\title{
Double Deviation Investigation Of Perceived Service Recovery Justice: A Study On The Indonesian Airline Industry
}

Jeanne Ellyawati, Universitas Atma Jaya Yogyakarta, Indonesia

\begin{abstract}
This study aimed to establish a fair service recovery model based on customer perception on the Indonesian domestic airline industry under force majeure conditions. The study tried to investigate the influence of perceived service recovery justice on service recovery satisfaction (SRS), repeat purchase, and word of mouth (WOM). A sample of 300 aircraft passengers was selected using a survey. The response rate was $84.33 \%$. Regression analysis was employed to verify the hypotheses. Based on the empirical research, it was found that perceived service recovery justice (distributive, procedural, and interactional justice) positively influenced SRS. Furthermore, the mean values of all three perceived justice variables were lower. Thus, it can be confirmed that double deviation occurred. The study also found that satisfied consumers tend to make repeat purchases and spread positive WOM. Consumers who experience dissatisfaction spread negative WOM but still make a repeat purchase. This indicates that even though customers experienced double deviation of service failures, they are still loyal to the company.
\end{abstract}

Keywords: Double Deviation; Service Recovery; Perceived Justice; Service Recovery Satisfaction

\section{INTRODUCTION}

enerally, a service failure is not anticipated. Nonetheless, it is bound to happen in any process involving an exchange and is difficult to avoid. Service failure occurs because consumer reality is often beyond the firm's expectations (Tax \& Brown, 1998). Most consumers who experience service failure will fall into the "consumer disappointment" category (Maxham, 2001). Factors causing service failure can be classified into internal and external factors. Service failure due to internal factors is controllable and should be anticipated by companies. Unfortunately, companies frequently have to face external factors that cannot be avoided or anticipated. Called force majeure, these factors are beyond human control and, as a result, the service activities cannot be carried out properly.

Service failure leads to disappointment and dissatisfaction among customers. Customers also tend to exhibit varying behavior, such as spreading negative word of mouth (WOM), curtailing purchase intentions, and even abandoning the company's products altogether (Ellyawati, Purwanto, Dharmmesta \& Herk, 2013). Service providers do not wish to face such a scenario. However, service failure in a business is not the end of everything. Many solutions can be used to address customer disappointment and restore trust and customer satisfaction. Integrated efforts through good communication, appropriate compensation, price discounts, vouchers, and good recovery procedures could increase customer satisfaction (Ellyawati, Purwanto \& Dharmmesta, 2012).

Marketing literature emphasizes that marketers should always make efforts to create customer satisfaction. When the focus is on customer satisfaction, it is expected that customers will make repeat purchases and buy more products. Satisfaction is a key to customer retention (Kotler \& Keller, 2016). Retaining existing customers is harder than acquiring new ones. Nevertheless, customer loyalty translates into good profitability (Craighead, Karwan \& Miller, 2004). The opportunity for service providers to regain the trust of customers after a service failure by employing a service recovery strategy has to be managed carefully and fairly; otherwise, the customer may become more disappointed and dissatisfied. Previous research has shown that the use of several service recovery efforts increases customer dissatisfaction (Hart, Heskett \& Sasser, 1990). Thus, poor service recovery in the event of a service failure 
may lead to a worse consumer evaluation and result in double deviation (Bitner, Booms \& Stanfield, 1990; Hart et al. 1990). Bitner et al. (1990) define double deviation as a response from the service system that is deemed improper and/or insufficient after a service failure.

When service providers deploy a good solution to cover service failure and perform optimally, it is expected that consumers will experience satisfaction and may even be more satisfied than before (service recovery paradox) (Magnini, Ford, Markowshi \& Honeycutt, 2007). As stated in marketing management literature, satisfaction is a predictor of consumer behavior (Kotler \& Keller, 2016; Solomon, 2015). Satisfied consumers tend to re-purchase the brand and spread positive WOM (Hocutt, Browers \& Donavan, 2006; Ellyawati et al., 2013). Conversely, unsatisfied consumers tend to leave the brand and will even retaliate by spreading negative WOM (Keaveney, 1995).

\section{LITERATURE REVIEW AND HYPOTHESIS DEVELOPMENT}

\section{Double Deviation}

Double deviation is the second stage of service failure. It arises as a result of the service provider failing to deliver SRS after a service failure. A customer who experiences a service failure and does not get satisfactory service recovery tends to trigger double deviation.

Studies about double deviation in service marketing, especially those on the airline industry and factoring force majeure conditions, are still limited. Past studies exploring the double deviation scenario focused on the banking industry (Johnston \& Fern, 1999; Casado-Diaz, Mas-Ruiz \& Kasper, 2007). Research conducted by Lee and Park (2010) examined the online retail industry. A study conducted by Johnston and Fern (1999) used an experimental design for collecting data. The study stated that $18 \%$ of customers who experienced double deviation tend to immediately abandon the product. However, satisfaction of customers who experienced double deviation of service failure can be achieved by providing high compensation and greater attentiveness/responsiveness coupled with an apology. Casado-Diaz et al. (2007) focused on distributive justice and emotions with service recovery. The study stated that a failed service recovery after a service failure arouses negative emotions such as anger, thereby leading to dissatisfaction. A study conducted by Lee and Park (2010) employed the CIT method for collecting data. The authors wanted to identify the type of service failure in double deviation scenarios. With the apparel product category as a research object, the cause of most double deviations is the time delay and delivery error.

\section{Perceived Justice}

Perception is defined as the process by which individuals select, organize, and interpret stimuli into a meaningful and coherent picture of the world (Schiffman \& Wisenblit, 2015). The theory of justice is borrowed from legal study that is intended to achieve social welfare in a country (Rawls, 1995). From the economics context, justice prevails when the marginal cost equals marginal revenue (Maryatmo \& Retnandari, 2006). In other words, justice is said to happen when one obtains the rights according to his/her contributions. Some people claim that justice is the same as fairness, meaning impartiality, rightness, and deservingness. The basic premise of fairness is that justice is not just objective (the principle of economy) but rather normative, which means that the fair is not only based on fact but also on social norms prevailing in the community (Fleurbaey \& Maniquet, 2011). The principle of justice is a fair exchange in which each party receives output in proportion to its contribution (Blodgett, Hill \& Tax, 1997). In other words, it is said that justice will be achieved when the right is equal to obligations (Maryatmo \& Retnandari, 2006).

From the context of the consumer attitudes model, perceived justice is a process of how the consumers assess service recovery from cognition aspects (Rio-Lanza, Casielles, Diaz-Martin, 2008; Solomon, 2015; Schiffman \& Wisenblit, 2015). Literature on marketing states that perceived recovery justice is an important variable for predicting customer satisfaction (Ellyawati et al., 2013). The theory of justice is built on the three dimensions of the justice concept: distributive justice, procedural justice, and interactional justice (Blodgett et al., 1997). 


\section{Distributive Justice}

Distributive justice is a consumer's evaluation of what he bought from the service provider, that is, whether it is worth the money he paid for it and the value he gained from the product. It can be either monetary or non-monetary compensation (McCollough, Berry \& Yadav, 2000). Distributive justice, in the form of non-monetary compensation, includes emotions (anger, embarrassment), the cost of complaints (time and effort), and benefits (McCollough et al., 2000). Distributive justice emphasizes on fair outcome, i.e., compensation from the service provider in the context of service failure (Blodgett et al., 1997). Outcome of distributive justice includes compensation in the form of discounts, coupons, refund, gifts, replacement, and apology (Blodgett et al., 1997; Tax, Brown \& Chandrashekaran, 1998; Hoffman \& Kelley, 2000). Studies conducted by Ellyawati et al. (2012) concluded that the variable of distributive justice is an important predictor of service recovery satisfaction. The study stated that when consumers were given a fair service recovery, they tended to perceive a high level of distributive justice, leading to consumer satisfaction (McCollough et al., 2000). Thus, the proposed hypothesis is:

H1: Perceived distributive justice tends to positively influence service recovery satisfaction (SRS)

\section{Procedural Justice}

Procedural justice is the consumer perception of fairness in the procedures, regulations, policies, and criteria used by the service provider as guidance in serving consumers in the daily activities (Ellyawati et al., 2013). Generally, the procedure is standardized in a company, which means the consumer is often powerless against poor procedures. From the service failure context, a poor procedure leads to service recovery dissatisfaction (Hocutt et al., 2006). However, a quick procedure would greatly affect customer satisfaction. Previous studies have stated that the faster the procedure, the higher the customer satisfaction (Ha \& Jang, 2009; Ellyawati et al., 2012). Based on this argument, the following hypothesis is proposed:

H2: Perceived procedural justice tends to positively influence SRS

\section{Interactional Justice}

Interactional justice is a communication between the service provider staff and customer during the process of solving the problem (Ellyawati et al., 2012). Previous studies have found that perceived interactional justice positively influences SRS (McCollough et al., 2000). When consumers perceive good interactional justice in terms of politeness, appreciation, and good communication from a friendly staff, they are likely to express SRS (Hocutt, Chakraborty \& Mowen, 1997, Rio-Lanza et al., 2008).

H3: Perceived interactional justice tends to positively influence SRS.

\section{Satisfaction, WOM, and Repeat Purchase}

Service recovery is very important for the service provider to restore consumer satisfaction after service failure. Service recovery is not just about providing a replacement (redressal) but also paying more attention to customer satisfaction. Customer satisfaction can be defined as a customer's evaluation of the extent to which the product's perceived performance has met his/her expectations (Kotler \& Armstrong, 2014). In other word, when a product's perceived performance meets expectations, the customer experiences satisfaction; likewise, when the product's perceived performance is below expectations, the customer experiences dissatisfaction.

Empirical studies have proved that customer satisfaction is an important variable in explaining behavioral intention (Saha \& Theingi, 2009, Wen \& Chi, 2013; Li, 2015) and post-purchase behavior, such as repurchase intention, WOM, and the willingness to pay more (Dolarslan, 2014). Implementation of this concept requires the service provider to satisfy the customer in order to retain him/her. Thus, if service failure has occurred, the service provider must be able to convert the consumer dissatisfaction into satisfaction. This can be done by providing excellent service recovery. Past studies have stated that implementing an effective recovery technique helps service providers retain existing customers or even increase customer loyalty (Chang, 2008). Previous studies have also proved that 
consumer satisfaction is an antecedent of positive WOM (Ha \& Jang, 2009; de Matos, Henruque \& de Rosa, 2013; Ellyawati et al., 2013). Therefore, consumers who experience satisfaction tend to increase repeat purchases and spread positive WOM. This argument leads to the following hypothesis:

H4: SRS will positively influence positive WOM.

H5: SRS will positively influence repeat purchases.

The relationships among constructs are illustrated in Figure 1.

Figure 1. Research Framework Model

Service Recovery

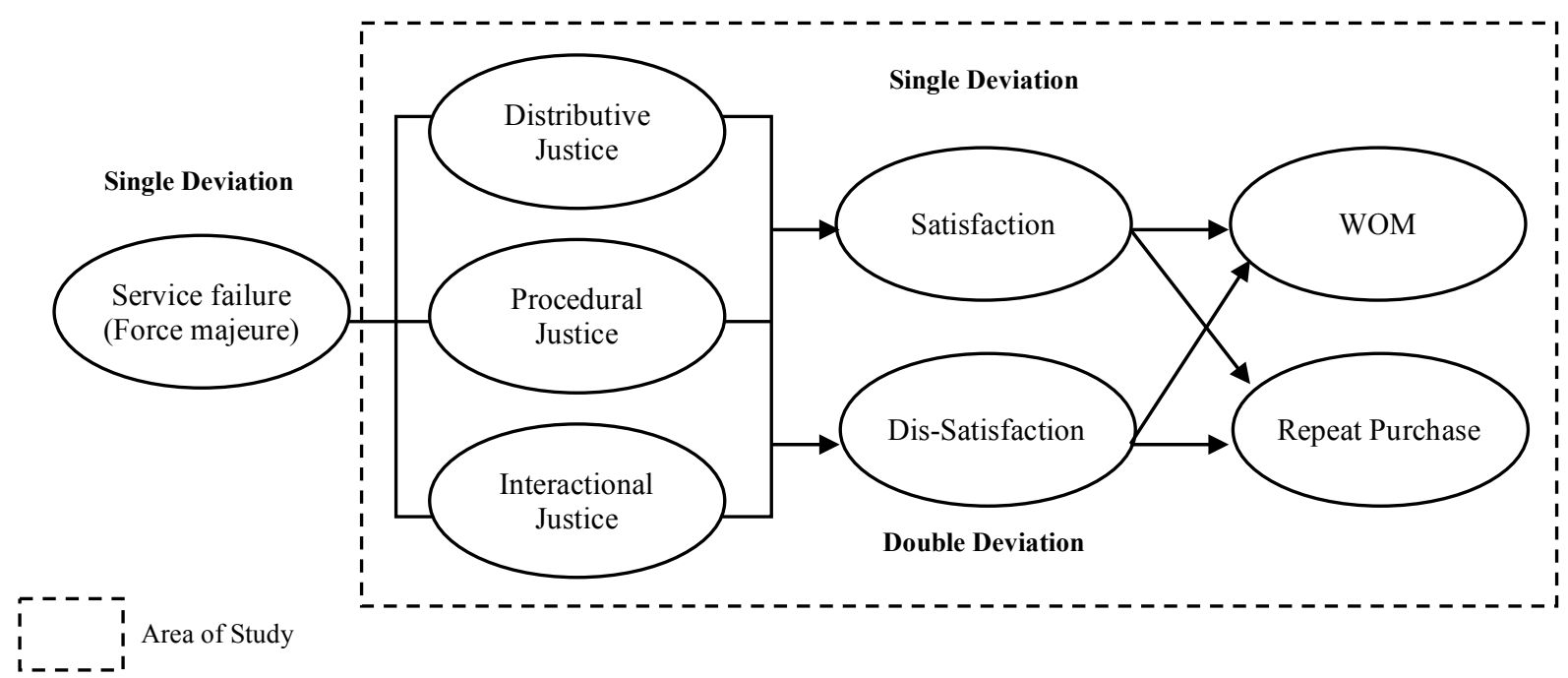

METHODOLOGY

\section{Sample and Data Collection}

The cross-sectional survey method was used to collect data. To maintain the heterogeneity of the sample size, only customers who experienced a service failure triggered by force majeure conditions were selected as respondents. Examples of force majeure conditions in the context of an airline include bad weather, floods, and earthquakes, which cause airplanes to not carry out their functions, resulting in delay or cancellation of flights. Respondents were asked to recall instances of service failure and answer a series of structured questions on consumer perceived justice, recovery satisfaction, and behavior after the incident. Data were collected in the Yogyakarta region of Indonesia in the year 2015. To obtain data that represented the population, this study recruited 300 respondents using the purposive sampling method (response rate: $84.33 \%$ ).

Based on the data collected, the study found that a majority of the passengers were women (58.7\%). Most of the respondents were aged between 26 to 35 years (79.4\%). More than half of the domestic airline passengers were married (52\%) and were graduates $(52.4 \%)$. Furthermore, most passengers used low-cost carriers $(80.7 \%)$ and they had traveled on 3-10 occasions over the past 12 months $(64.1 \%)$.

\section{Measures}

Each of these constructs was measured with multi-item indicators. A five-point Likert scale was developed to measure the observed variables, with a range from "strongly agree" to "strongly disagree." All variables were 
measured by adopting the research instrument used in the study conducted by Ellyawati et al. (2013) with modifications as needed. The validity of the scales was assessed with Pearson's correlation; the confidence level was $95 \%$. As the loading factor was greater than or equal to 0.6 (Hair, Black, Babin, Anderson \& Tatham, 2010), the research instrument can be considered valid. The reliability test is concerned with the accuracy and precision of a measurement procedure (Cooper \& Schindler, 2008). Reliability estimation is considered to be reliable when Cronbach's alpha has a minimum score of 0.7 . This study found that all items are valid and reliable.

To verify the hypothesis, multiple linear regression was employed using the SPSS V.23 program. By using the $95 \%$ level of confidence, if p-value is smaller than 0.05 , then independent variables significantly affect the dependent variable. If beta value is positive, it means the dependent variable is in the same direction as the independent variable and in the opposite direction otherwise. The coefficient of determination $\left(R^{2}\right)$ shows the ability of the variations of the independent variables in explaining the variation of the dependent variable. The $R^{2}$ value falls between 0 and 1 . For the estimation model, the greater the value of $\mathrm{R}^{2}$, the better is the estimate.

\section{RESULTS}

\section{Influence of Perceived Justice on Customer Satisfaction}

The study found that perceived distributive justice positively and significantly influences recovery satisfaction $(\beta=+0.194, p<0.05)$. This means that perceived distributive justice tends to influence SRS in the same direction. Thus, the study supports hypothesis H1. Based on the result, procedural justice is seen to positively and significantly influence SRS $(\beta=+0,219, \mathrm{p}<0.05)$. This means that perceived procedural justice tends to influence SRS in the same direction. Therefore, the study supports hypothesis H2. The relationship between interactional justice and SRS found that perceived interactional justice positively and significantly influences SRS $(\beta=+0,521, p<0.05)$. This means that perceived interactional justice tends to influence SRS in the same direction. Therefore, the study supports hypothesis $\mathrm{H} 3$.

Furthermore, it can be interpreted that when customers perceived fair recovery (distributive, procedural, and interactional), they will experience satisfaction. Conversely, when customers perceived unfair recovery, they will experience dissatisfaction. The strength of the relationship among justice variables can be seen through Adjusted $\mathrm{R}^{2}$. The influence of distributive justice, procedural justice, and interactional justice on satisfaction is $\mathrm{R}^{2}=0.738$. This means that $73.80 \%$ of customer satisfaction is influenced by the perceived distributive justice, procedural justice, and interactional justice. Likewise, $26.20 \%$ is influenced by other factors not examined in this study (see Table 1).

\section{Influence of Recovery Satisfaction on WOM}

The regression output showed that SRS significantly and positively influences WOM. This is indicated by the standardized coefficient beta $\left(\beta=+0.679, \mathrm{p}<0, \mathrm{R}^{2}=0.459\right.$; see Table 1$)$. This means that there is a tendency that an increment in SRS will increase WOM. Furthermore, it can be inferred that if customers experience satisfaction, they will spread positive WOM. When customers experience dissatisfaction, they will spread negative WOM. The $\mathrm{R}^{2}$ value indicates a moderate relationship. Thus, the study fully supports hypothesis H4.

\section{Influence on Recovery Satisfaction on Repeat Purchase}

The study found that SRS affects repurchase intention significantly and in a positive direction $(\beta=+0.442, p<0.05)$. When customers experience satisfaction, they tend to repurchase the service. Conversely, when customers experience dissatisfaction, they tend to refrain from buying the service. The relationship between SRS and repeat purchases is indicated by $R^{2}=0.192$. Even though the $R^{2}$ value is low, the F-test value is significant. The significance level in the F-test means that the variation of the independent variable could explain the variation of the dependent variable. Thus, this study supports hypothesis H5. 
Table 1. Output of Regression Weight

\begin{tabular}{|c|c|c|c|c|c|c|}
\hline \multirow[b]{2}{*}{ Description } & \multirow{2}{*}{$\begin{array}{l}\text { Standardized } \\
\text { coefficients } \beta\end{array}$} & \multicolumn{2}{|c|}{ t-test } & \multicolumn{2}{|c|}{ F-test } & \multirow{2}{*}{ Adj R } \\
\hline & & t-value & Sig. & F-value & Sig. & \\
\hline $\mathrm{DJ} \rightarrow$ Sat & $+0,194$ & 3,853 & 0,000 & \multirow{3}{*}{230.988} & \multirow{3}{*}{.000} & \multirow{3}{*}{0,738} \\
\hline $\mathrm{PJ} \rightarrow$ Sat & $+0,219$ & 3,852 & 0,000 & & & \\
\hline $\mathrm{IJ} \rightarrow$ Sat & $+0,521$ & 9,425 & 0,000 & & & \\
\hline Sat $\rightarrow$ WOM & $+0,679$ & 14,552 & 0,000 & 210.879 & .000 & 0,459 \\
\hline Sat $\rightarrow$ RP & $+0,442$ & 7,737 & 0,000 & 59.859 & .000 & 0,192 \\
\hline
\end{tabular}

Table 2. Mean of Observed Variable

\begin{tabular}{|c|c|c|c|}
\hline Variable & Total item & Mean & Discription \\
\hline Distributive & 5 & 2,981 & Low \\
\hline Procedural & 5 & 2,992 & Low \\
\hline Interactional & 6 & 2,974 & Low \\
\hline Satisfaction & 7 & 2,907 & Low \\
\hline Positive WOM & 4 & 2,696 & Low \\
\hline Repeat purchase & 3 & 3,034 & Fair \\
\hline
\end{tabular}

\section{Perceived Justice, Satisfaction, and Double Deviation}

To see whether the service recovery in this study is a single or double deviation, we should look at the mean value of the perceived recovery justice for each variable and SRS. If the mean value is more than 3, then the consumer is considered to experience satisfaction; else, the customer is considered to experience dissatisfaction. Based on descriptive statistics, the mean values of perceived distributive justice, procedural justice, and interactional justice, respectively, are 2.981, 2.992, and 2.974 (see Table 2). In other words, all mean values are less than 3 . This indicates that service recovery does not fulfill customer expectations. Compensation was perceived to be unfair, and procedures and policies of the service provider did not solve the problem; furthermore, communication and interaction with customers was also considered inadequate. The mean value of customer satisfaction is 2.907 (see Table 2). This means that service recovery in terms of compensation, procedure, and interaction with the airlines staff was not sufficient to treat customer disappointment. Thus, it is empirically proved that customer experienced dissatisfaction. It can be concluded that double deviation occurred in this study as the perceived distributive justice, procedural justice, and interactional justice did not satisfy customers.

Based on the data, it is found that the mean value of repeat purchases is 3.034. This indicates that although customers experienced double deviation, they still want to buy the service. However, since the mean value is only a little above the average in the category interval scale, it can be concluded that their loyalty reached the lowest satisfaction category. This happened because there was no promising service that substituted the service provided. When there is another better service available, consumers will easily move on to another product. This process is often referred to as spurious loyalty.

\section{DISCUSSION AND CONCLUSION}

Most studies have explored service failure from the company's standpoint. This study tried to analyze service failure from the customers' point of view, considering force majeure conditions. Generally, customers will understand and acknowledge service failure caused by a force majeure condition, because they know that such failure is not company's fault. Unfortunately, most companies do not pay attention to regulations and do not carry out obligations properly, and as a result, customers think that they were treated unfairly. This leads to double deviation.

A study by Johnston and Fern (1999) indicated that a majority (76\%) of customers wanted fair compensation. When customers perceived the compensation received as unfair, they were disappointed and dissatisfied. Therefore, it can be said that perceived distributive justice positively affects customer satisfaction (Casado-Diaz et al., 2007). Prompt response and correction are essential to restore customer dissatisfaction. Previous research (Ellyawati et al., 2012) 
has also shown that besides compensation, interaction with customers is very important. Although distributive justice is sometimes not enough to restore customer dissatisfaction, good communication with customers can convert their dissatisfaction into satisfaction. The most efficient means of service recovery is providing excellent service that is distinct from that of competitors ( $\mathrm{Li}, 2015)$. This study is in agreement with previous studies, which found that distributive, procedural, and interactional justice affect customer satisfaction.

Maxham and Netemeyer (2002) stated that when customers receive service recovery that is below their expectations, they will be more disappointed than they were when they encountered the first failure. When customers experience dissatisfaction after service recovery (double deviation), they tend to curb repurchases and spread negative WOM. This study confirms the findings of previous studies that state that consumers who experience satisfaction tend to opt for repeat purchases (Casielles, Igesias \& Neira, 2012) and are likely to spread positive WOM, and negative WOM when they are dissatisfied. However, even though the mean values of perceived justice and satisfaction are low, the mean value of repeat purchase is fair. This is because no better service is available to fulfill customers' need. The Indonesian airlines industry, being an oligopolistic market, has very few companies. Furthermore, not all airlines provide many options in terms of destination selection, flight schedule, and low price.

\section{MANAGERIAL IMPLICATIONS}

The study found that customer satisfaction is influenced by perceived recovery justice. Low perceived recovery justice caused low SRS. The biggest influences of perceived recovery justice on SRS were perceived procedural justice, interactional justice, and distributive justice. Thus, consumer satisfaction is determined by an excellent service recovery procedure, communication with company staff, and compensation. Based on the mean value, the three dimensions of perceived justice exhibit an average value of less than 3. This suggests that consumers' response to compensation, procedures, and interactions is still lacking. It can be said that the service recovery provided by the company is not sufficient to restore customer satisfaction.

Judging from the mean value of the three justice dimensions, the lowest value is interactional justice. Previous studies have stated that although sometimes compensation is not enough to satisfy customers, when the interaction with consumers is good, they are still likely to experience satisfaction (Ellyawati et al., 2012). Thus, the airline has to pay more attention to interactional justice through actions such as prompt response, politeness, listening to the customer's problem personally, and striving to address the problem in a sensible manner.

If compensation is considered a cost burden and the company is still trying to establish its systems and procedures and determining reasonable compensation figures, the company can train its staff to provide the best service. As a tool, it has been able to reduce the anger and disappointment caused by service failure. When the staff is trained to provide excellent service, it is expected that consumers will experience satisfaction and, in turn, double deviation will be avoided. Furthermore, customer satisfaction can also positively affect repeat purchases and WOM. It is expected that consumers who experience satisfaction will make repurchases and spread positive WOM. It would be more beneficial for the company to use this strategy than rely on a pricing strategy (Casado, Nicolau \& Mas-Ruiz, 2011).

Indonesian people are very tolerant customers and, of course, this is an advantage for the company. The results of the study show that although consumers experienced service failures, they were willing to forgive the company and would even like to make repeat purchases. However, it needs to be investigated further whether customers are indeed loyal to the brand, have not found a better alternative yet, are inert, display spurious loyalty, face high switching costs $(\mathrm{Li}, 2015)$ or any other factors are responsible.

\section{Limitations of the Study and Directions for Future Research}

The compensation offered by service providers (airlines) actually varies. However, in this study, the compensation offered by the airline has not been specified in detail. Future research should focus on the compensation (distributive) in detail so that it can be used by the service provider to serve its customers better. The study did not distinguish between high- and low-cost carriers. For future research, it is advisable to separate them, because different classes will have different level of services and prices. 


\section{ACKNOWLEDGEMENTS}

This research is supported by the Directorate General of Higher Education, Ministry of Research, Technology and Higher Education of the Republic of Indonesia, and the Atma Jaya Yogyakarta University, Indonesia.

\section{AUTHOR BIOGRAPHY}

Jeanne Ellyawati is a lecturer at the Graduate Program, Department of Management, Faculty of Economics, Atma Jaya Yogyakarta University, Indonesia. She got her Ph.D. from the Faculty of Business and Economics, Gadjah Mada University, Indonesia. Her research interests lie in the areas of service marketing and consumer behavior. Her articles have been published in national and international peer-reviewed journals.

\section{REFERENCES}

Bitner, M.J., Booms, B.H., \& Stanfield, M.T. (1990). The service encounter: diagnosing favorable and unfavorable incidents. Journal of Marketing, 54, 71-84.

Blodgett, J.G., Hill, D.J., \& Tax, S.S. (1997). The effects of distributive, procedural interactional justice on post complaint behavior. Journal of Retailing, 73(2), 185-210.

Casado, A.B., Nicolau, J.L., \& Mas-Ruiz, F.J. (2011). The harmful consequences of failed recovery in the banking industry. International of Bank Marketing, 29(1), 32-49.

Casado-Diaz, A.B., Mas-Ruiz, F.J., \& Kasper, H. (2007). Explaining satisfaction in double deviation scenarios: the effects of anger and distributive justice. International Journal of Bank Marketing, 25(5), 292-314.

Casielles, R.V., Iglesias, V., \& Neira, C.V. (2012). Service recovery, satisfaction and behavior intentions: analysis of compensation social comparison communication strategies. The Service Industries Journal, 32(1), 83-103.

Chang, C. (2008). Choice, perceived control, and customer satisfaction: The psychology of online service recovery. Cyber Psychology and Behavior, 11(3), 321-328.

Cooper, D.R., \& Schindler, P. (2008). Business research methods. $10^{\text {th }}$ ed., Singapore: McGraw-Hill.

Craighead, C.W., Karwan, K.R., \& Miller, J.L. (2004). The effects of severity of failure customer loyalty on service recovery strategies. Journal of Production Operations Management, 13(4), 307-321.

De Matos, C.A., Henrique, J.L., \& de Rosa, F. (2013). Customer reactions to service failure and recovery in the banking industry: the influence of switching costs. Journal of Service Marketing, 27(7), 526-538.

Dolarslan, E.S. (2014). Assessing the effects of satisfaction and value on customer loyalty behavior in service environment. Management Research Review. 37(8), 706-727.

Ellyawati, J., Purwanto, B.M., \& Dharmmesta, B.S. (2012). The effect of perceived justice on consumer satisfaction in the service recovery context: testing mediating variables. Journal of Service Science, 5(2), 87-100.

Ellyawati, J., Purwanto, B.M, Dharmmesta, B.S., \& Herk, H.V. (2013). Perceived justice in service recovery: study of experimental design on Indonesian customers. International Journal of Business Management Studies, 2(2), 511-522.

Fleurbaey, M., \& Maniquet, F. (2011), Theory of fairness and social welfare, New York, USA: Cambridge University Press.

Hair, J.F., Black, W.C., Babin, B.J., Anderson, R.E., \& Tatham, R.L. (2010). Multivariate data analysis. $7^{\text {th }}$ ed., Upper Saddle River, New Jersey: Pearson Education, Inc.

Ha, J., \& Jang, S.C. (Hawn). (2009). Perceived justice in service recovery and behavioral intentions: the role of relationship quality. International Journal of Hospitality Management, 1-9.

Hart, C.W.L., Heskett, J.L., \& Sasser, W.E. (1990). The profitable art of service recovery. Harvard Business Review, 68, 148156.

Hocutt, M.A., Browers, M.R., \& Donavan, D.T. (2006). The art of service recovery: fact or fiction?. Journal of Service Marketing, 20(3), 199-207.

Hocutt, M.A, Chakraborty, G., \& Mowen, J.C. (1997). The impact of perceived justice on customer satisfaction and intention to complain in a service recovery. Advance in Consumer Research, 24, 457-463.

Hoffman, K.D., \& Kelley, S.W. (2000). Perceived justice needs and recovery evaluation: a contingency approach. European Journal of Marketing, 34(3/4), 418-432.

Johnston, R., \& Fern, A. (1999). Service recovery strategies for single and double deviation scenarios. The Service Industries Journal, 19(2), 69-82.

Keaveney, S.M. (1995). Customer switching behavior in service industry: an exploratory study. Journal of Marketing, 59(2), 7182.

Kotler, P., \& Armstrong, G. (2014). Principle of marketing, 15e $\mathrm{e}^{\text {th }}$ ed., Edinburgh Gate, Harlow, Essex, England: Pearson Education Limited.

Kotler, P., \& Keller, K.L. (2016). Marketing management, 15e $\mathrm{e}^{\text {th }}$ ed., Edinburgh Gate, Harlow, Essex, England: Pearson Education Limited. 
Lee, E.J., \& Park, J.K. (2010). Service failures in online double deviation scenarios: justice theory approach. Managing Service Quality, 20(1), 46-69.

Li, Chia-Ying (2015). Switching barriers and customer retention why customers dissatisfied with online service recovery remain loyal. Journal of Service Theory and Practice, 25(4), 370-393.

Magnini, V.P., Ford, J.B., Markowski, E.P., \& Honeycutt, E.D. (2007). The service recovery paradox: justifiable theory or smoldering myth? Journal of Services Marketing, 21(3), 213-225.

Maryatmo, R., \& Retnandari (2006). Ekonomi kesejahteraan, Yogyakarta: Universitas Atma Jaya Yogyakarta.

Maxham, J.G. (2001). Service recovery's influence on consumer satisfaction, positive word-of-mouth, and purchase intention. Journal of Business Research, 54, 11-24.

Maxham, J.G., \& Netemeyer, R.G. (2002). A longitudinal study of complaining customers' evaluations of multiple service failures and recovery efforts. The Journal of Marketing, 66(4), 57-71.

McCollough, M.A., Berry, L.L., \& Yadav, M.S. (2000). An empirical investigation of customer satisfaction after service failure and recovery. Journal of Service Research, 3(2), 121-137.

Rawls, J. (1999). A theory of justice, revised edition. Harvard University Press: Cambridge, Massachusetts.

Rio-Lanza, A.B., Casielles, R.V., \& Diaz-Martin, A.M. (2008). Satisfaction with service recovery: Perceived justice and emotional responses. Journal of Business Research, 1-7.

Saha, G.C., \& Theingi. (2009). Service quality, satisfaction, and behavioral intentions, A study of low cost airline carriers in Thailand. Managing Service Quality, 19(3), 350-372.

Schiffman, L.G., \& Wisenblit, J. (2015). Consumer behavior, $11^{\text {th }}$ ed. Edinburgh Gate, Harlow, Essex, England: Pearson Education Limited.

Solomon, M.R. (2015). Consumer behavior: buying, having and being. $11^{\text {th }}$ ed., Edinburgh Gate, Harlow, Essex, England: Pearson Education Limited.

Tax, S.S., \& Brown, S.W. (1998). Recovering and learning from service failure. Sloan Management Review, 40 (1), 75-88.

Tax, S.S., Brown, S.W., \& Chandrashekaran, M. (1998). Customer evaluations of service experiences: implication for relationship marketing. Journal of Marketing, 62, 60-76.

Wen, B., \& Chi, C.G.Q. (2013). Examine the cognitive and affective antecedents to service recovery satisfaction a field study of delayed airline passengers. International Journal of Contemporary Hospitality Management, 25(3), 306-327. 


\section{NOTES}

